\title{
Anti-inflammatory Activity of Isolated Compounds from the Stem Bark of Garcinia cowa Roxb
}

\author{
Fatma Sri Wahyuni ${ }^{1}$, Daud Ahmad Israf Ali ${ }^{2}$, Nordin Hj. Lajis ${ }^{3}$ and Dachriyanus ${ }^{1}$
}

Fatma Sri Wahyuni ${ }^{1}$, Daud Ahmad Israf Ali ${ }^{2}$, Nordin Hj. Lajis ${ }^{3}$ and Dachriyanus ${ }^{1}$

'Faculty of Pharmacy, Andalas University, Kampus Limau Manis, Padang, West Sumatra, Indonesia, 25163 ${ }^{2}$ Faculty of Medicine and Health Sciences, University Putra Malaysia 43400 UPM, Serdang, Selangor, Malaysia

${ }^{3}$ Laboratory of Natural Products, Institute of Bioscience, University Putra Malaysia, 43400 UPM, Serdang, Selangor, Malaysia.

Correspondence

Fatma Sri Wahyuni, Faculty of Pharmacy, Andalas University, Kampus Limau Manis, Padang, West Sumatra, Indonesia, 25163

Tel.: +6275171682;

Fax: +62751777057

Mobile phone: +6281374024514

Email: fatmasriwahyuni@gmail.com History

- Submission Date: 15-09-2016

- Review completed: 30-09-2016;

- Accepted Date: 05-11-2016.

DOI : 10.5530/pj.2017.1.10

Article Available online http://www.phcogj.com/v9/i1

\section{Copyright}

(C) 2016 Phcog.Net. This is an openaccess article distributed under the terms of the Creative Commons Attribution 4.0 International license.

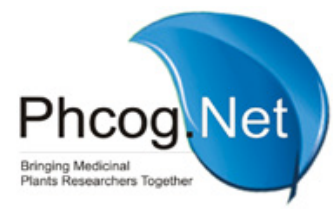

\begin{abstract}
Objective: To find the anti inflammatory active compounds from methanol extract of Garcinia cowa Methods: To evaluate the inhibitory activity of isolated compounds on nitric oxide (NO) production, culture media was assayed using Griess reaction. An equal volume of Griess reagent ( $1 \%$ sulphanilamide and $0.1 \% \mathrm{~N}$-(L-naphthyl)-ethylene diamine dihydrochloride, dissolved in $2.5 \% \mathrm{H} 3 \mathrm{PO} 4$ ) was mixed with culture supernatant and color development was measured at $550 \mathrm{~nm}$ using a micro plate reader. The amount of nitrite in the culture supernatant was calculated from a standard curve $(0-100 \mu \mathrm{M})$ of sodium nitrite freshly prepared in deionized water. Percentage of the NO inhibition was calculated by using nitrate level of IFN- $\gamma / \mathrm{LPS}$-induced group as the control. Results: Isolated compounds, tetraprenyltoluquinone, rubraxanthone and $\alpha$-mangostin from stem bark of Garcinia cowa Roxb were evaluated for their anti-inflammatory activity. Only $\alpha$-mangostin exhibited strong anti-inflammatory activity with $83.42 \%$ inhibition of NO and without inducing severe cytotoxicity at $50 \mu \mathrm{M}$. Rubraxanthone showed weak inhibition of NO with $23.86 \%$ inhibition of NO while maintained $77.32 \%$ of cell viability. TPTQalso showed the strong inhibition of NO with $80.98 \%$ inhibition but unfortunately this compound also induced severe cytotoxicity with $39.62 \%$ viability. Conclusion: $\alpha$-Mangostin exhibited strong anti-inflammatory activity without inducing severe cytotoxicity at $50 \mu \mathrm{M}$. Rubraxanthone showed weak inhibition of NO while Tetraprenyltoluquinone also showed the strong inhibition of NO however this compound also induced severe cytotoxicity.
\end{abstract}

Key words: Nitric oxide, Anti-inflammatory, Garcinia cowa, Rubraxanthone, $\alpha$-mangostin, tetrapreniltoluquinone

\section{INTRODUCTION}

The inflammatory disease as manifested in rheumatism, allergies and asthma is increasing. About $10 \%$ of the children are said to have asthmatic disorders. Although several different steroids and NSAIDS such as celecoxib, aspirin, ibuprofen, and phenylbutazole have been approved for treatment of inflammatory conditions, most of them have side effects, especially when consumed over long periods of time. ${ }^{1}$ Therefore, the empirical approach to discover new drugs with less side effects via the systematic screening of plants extracts still remains an interesting strategy to find new lead compounds. ${ }^{2}$

In our preliminary study, the methanol extracts of eight species of different parts of Garcinia spp. were evaluated for their cytotoxicity and anti-inflammatory activity using MTT and Griess assay method, respectively. ${ }^{3}$ Ethanol extract of the stem bark of G. cowa also active on T47D breast cancer cell. Several compounds, [2E ,6E ,10E ]-(+)-4b -hydroxy-3-methyl-5b -(3,7,11,15-tetramethyl-2,6,10,14-hexadecatetraenyl2-cyclohexen-1-one (1), 6-hydroxycalabaxanthone (2), 2-(3-methyl-2-butenyl)-1,5,6-trihydroxy-3-methoxy-4-(1,1-dimethyl-2-propenyl)-9H-xanthen- 9-one (3), rubraxanthone (4), $\alpha$-mangostin (5), a new compound 1,3,6-trihydoxy-7-methoxy-4-(4acetoxy-3-methyl-2-butenyl)-8-(3,7-dimethyl2,6-octadienyl)xanthone (6) and cowanin (7) were isolated from this part. ${ }^{5,6}$ In this paper anti inflammatory study of isolated compound from the stem bark of G. cowa was reported.

\section{MATERIALS AND METHODS}

\section{Instruments}

Holten Laminar microbiological safety cabinet class II was obtained from Heto-Holten (Allerød, Denmark). Galaxy R CO2 incubator was from RS Biotech (Ayrshire,Scotland). A micro plate reader with SOFTmax ${ }^{\oplus}$ Prosoftware (Versamax, Molecular Devices, California, USA) was used to measure the absorbance of formazan solution.

\section{Plant material and compound isolation}

\section{Plant material:}

Garcinia cowa Roxb (stem bark, leaves and roots) was collected at Sarasah Bonta, Harau Valley, and West Sumatra at an altitude of $500 \mathrm{~m}$. The ucher specimens (DR-180) 

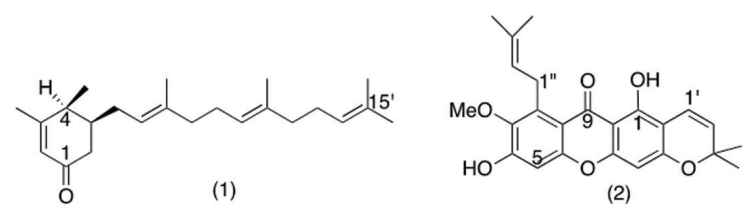

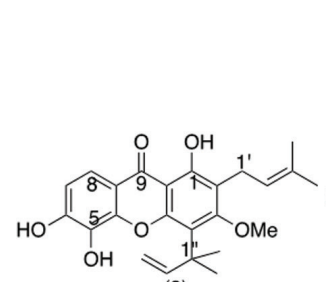

(3)
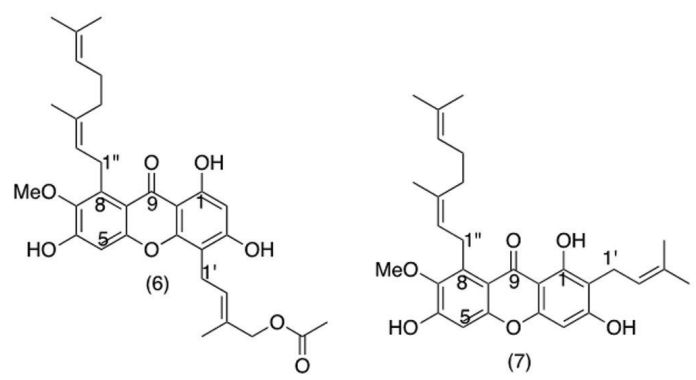

were identified by Dr Rusdi Tamin and were deposited in the herbarium of Andalas University, Padang, Indonesia. Plant materials were cut into small pieces (3-5 mm thickness) and air-dried under shade. The dried plant materialswere ground to powder before extraction. Tetraprenyltoluquinone, a-mangostin, and rubraxanthone were isolated from the stem bark of G. cowa according to the method described earlier. ${ }^{6}$

\section{Preparation of extracts and compounds}

The methanol extracts and compounds were prepared by dissolving in DMSO to make stock solutions of $100 \mathrm{mg} / \mathrm{mL}$ and $100 \mathrm{mM}$, respectively. All drug solutions were aliquot into appropriate volume and stored refrigerated at $-20^{\circ} \mathrm{C}$ priors to use.

\section{Cell culture}

RAW264.7 cell line was obtained from American Type Culture Col- lection (ATCC), USA. Dulbecco's Modified Eagle Medium (DMEM) both with and without phenol red, phosphate buffered saline and Hanks' balanced salt solution (HBSS), 3-(4,5-Dimethylthiazol-2-yl)- 2,5-diphenyltetrazoliumbromide (MTT), phosphate buffered saline (PBS) and Griess reagent were from Invitrogen (Carlsbad, USA). Foetal bovine serum (FBS), LPS from E. coli serotype 0111:B4, Indomethacin, L-NAME [L-NG-nitroarginine methyl ester (hydrochloride)], dimethyl- sulfoxide (DMSO), and sodium nitrite were obtained from Sigma (St Louis, USA). Interferon gamma (IFN $\gamma$ ) was from BD Biosciences (New Jersey, USA). NF- $\kappa B$ translocation kit was from Cellomics (Pitts- burg, USA). All other chemicals and reagents used were of HPLC grade.

The murine monocyte macrophage cell line (RAW 264.7) was maintained in DMEM supplemented with 10\% FBS, 4.5 g/l glucose, so- dium pyruvate $(1 \mathrm{mM})$, L-glutamine $(2 \mathrm{mM})$, streptomycin $(50 \mu \mathrm{g} / \mathrm{ml})$ and penicillin $(50 \mathrm{U} / \mathrm{ml})$ at $37^{\circ} \mathrm{C}$ and $5 \% \mathrm{CO} 2$. Cells at confluence of $80-90 \%$ were centrifuged at $120 \times \mathrm{g}$ at $4^{\circ} \mathrm{C}$ for $10 \mathrm{~min}$ and cell con-centration was adjusted to $(2 \times 106)$ cells $/ \mathrm{ml}$, whereby the cell viability always more than $90 \%$, as determined by trypan blue exclusion. A total of $50 \mu \mathrm{L}$ of cell suspension was seeded into a tissue culture grade 96 -well plate $(4 \times 105$ cells/well) and incubate for $2 \mathrm{~h}$ at $37^{\circ} \mathrm{C}, 5 \% \mathrm{CO} 2$ for cells attachment. Then, the cells were stimulated by using $100 \mathrm{U} / \mathrm{ml}$ of IFN- $\gamma$ and $5 \mu \mathrm{g} / \mathrm{ml}$ of
LPS with or without the presence of columbine tested at the final volume of $100 \mu \mathrm{L} /$ well. DMSO was used as vehicle, where the final concentration of DMSO was maintained at $0.1 \%$ of all cultures. Cells were further incubated at $37^{\circ} \mathrm{C}, 5 \% \mathrm{CO} 2$ for $20 \mathrm{~h}$. The culture supernatant was subjected to Griess assay for nitrite determination and the cells remaining in the well were tested for cell viability assay by using MTT reagent.

\section{In vitro test for anti-inflammatory activity - Griess assay}

To evaluate the activity of extracts in inhibiting NO production, the Griess assay was employed (modified method of Dirsch et al., 1988).? Briefly, RAW 264.7 cells (murine monocytes macrophage) were stimulated to produce inflammation using recombinant mouse IFN- $\gamma$ (BD Pharmingen, USA) and lipopolysaccharide (LPS) (from Escherichia coli). To evaluate the NO inhibitory activity of extracts, Griess reagent (1\% sulfanilamide/ $0.1 \% N$-(1-naphtyl) ethylene diamine dihydrochloride in $2.5 \% \mathrm{H}_{3} \mathrm{PO}_{4}$ ) was mixed with an equal part of cell culture medium of control and extracts treated RAW 264.7 cells. The color development corresponding to NO level was assessed at $550 \mathrm{~nm}$ with a micro plate reader (Spectramax, Plus 384, Molecular Devices, Inc., USA). The percentage NO inhibition was determined according to the formula below. This was followed by cell viability determination using the MTT assay as describe above:

\section{No level of control - No level of extract treated cells$$
\text { No level of control cells }
$$

\section{RESULTS}

Isolated compounds, tetraprenyltoluquinone, rubraxanthone and a-mangostin from stem bark of Garcinia cowa Roxb were evaluated for their anti-inflammatory activity. The result can be showed in Table 1.

\section{DISCUSSION}

Inflammation is a pathophysiological process mediated by a variety of signaling molecules produced mainly by leukocytes, macrophages and plasma cells. Macrophages play a crucial role in the generation of the pro-inflammatory molecule nitric oxide (NO). NO is generated at high levels during human inflammatory reaction. NO synthesized by the enzyme inducible nitric oxide synthase (iNOS) has been reported as a mediator of acute and chronic inflammations. ${ }^{8}$ Studies have shown that macrophages upon stimulation with bacterial lipopolysaccharide (LPS) express iNOS to produce large amount of NO. iNOS is one of the essential components of the inflammatory response and is involved in the pathogenesis of several inflammatory diseases such as asthma and rheumatoid arthritis. In this study, using Griess assay to measure the level of NO produced by activated murine RAW 264.7 macrophage cells, plants extracts were evaluated for their anti inflammatory activity.

$\mathrm{NO}$ may induce toxic reactions against other tissues of the host when it is generated at high levels in certain types of inflammation, for example asthma. NO also has been implicated as a pro-inflammatory agent. ${ }^{9}$ Nitric oxide (NO) is a signal molecule with functions such as neurotransmission, local vascular relaxation and anti-inflammation in many

Table 1: No inhibitory activity of isolated compounds

\begin{tabular}{cccc}
\hline No & Compounds & $\begin{array}{c}\text { \% inhibition } \\
\text { of NO } \\
(50 \mu \mathrm{M})\end{array}$ & $\begin{array}{c}\% \text { viability of } \\
\text { RAW cell } \\
(50 \mu \mathrm{M})\end{array}$ \\
\hline 1. & Tetrapreniltoluquinone $(1)$ & 81 & 40 \\
2. & rubraxanthone (4) & 24 & 77 \\
3. & a-mangostin(5) & 83 & 82 \\
\hline
\end{tabular}


physiological and pathological processes. Due to its high reactivity in biological systems, it is transformed in the bloodstream into nitrates (NO3-) by oxyhemoglobin. The Griess reaction is a technically simple method (spectrophotometric, $540 \mathrm{~nm}$ ) for the analysis of nitrites (NO2-) in aqueous solutions. ${ }^{10}$

Three compounds were evaluated for the inhibition of NO production. Only $\boldsymbol{\alpha}$-mangostin (5) exhibited strong anti-inflammatory activity with $83.42 \%$ inhibition of $\mathrm{NO}$ and $82.36 \%$ cell viability. Anti-inflammatory activity of $\boldsymbol{\alpha}$-mangostin (5) has been reported before by Chen et al., (2008). ${ }^{7}$ Rubraxanthone (4)showed weak inhibition of NO with $23.86 \%$ inhibition value of NO and $77.32 \%$ of cell viability. Compound (1) also showed the strong inhibition of NO with $80.98 \%$ inhibition but it also kill the RAW cell with $39.62 \%$.viability.

\section{CONCLUSION}

In conclusion, $\boldsymbol{\alpha}$-mangostin (5) exhibited strong anti-inflammatory activity without inducing severe cytotoxicity. Rubraxanthone (4) showed weak inhibition of NO while tetraprenyltoluquinone (1) showed the strong inhibition of NO inhibition however this compound also induced severe cytotoxicity.

\section{ACKNOWLEDGEMENTS}

The author thank the Malaysian Ministry of Science, Technology and the Environment are thanked for financial support under the Intensified Research in Priority Areas Research Grant (IRPA, EAR No. 09-02-04-0313), International Foundation for Science (IFS no F/3967-1), National L'Oreal Fellowship and Higher Education Grant from Ministry of Education Indonesia

\section{REFERENCES}

1. Iwu MM. Ethno botanical approaches to pharmaceutical drug discovery, strengths and limitations. Ethno Medicine and Drug Discovery. 2002 31;1:309-20.

2. Mc Chesney JD. Plant natural products: back to the future or into extinction? Phytochemistry. 2007;68(14):2015-22. http://dx.doi.org/10.1016/j.phytochem. 2007.04.032; PMid:17574638

3. Jabit ML, Wahyuni FS, Khalid R, Israf DA, Shaari K, Lajis NH, et al. Cytotoxic and nitric oxide inhibitory activities of methanol extracts of Garcinia species, Pharm Biol. 2009;47(11):1019-26. http://dx.doi.org/10.3109/13880200902973787

4. Husni E, Nahari F, Wirasti Y, Wahyuni FS, Dachriyanus. Cytotoxicity study of ethanol extract of the stem bark of asam kandis (Garcinia cowa Roxb.) on T47D breast cancer cell line. Asian Pac J Trop Biomed. 2015;5(3):249-52. http://dx.doi. org/10.1016/S2221-1691(15)30013-7

5. Wahyuni FS, Lindsay TB, Dachriyanus, Dianita R, Jubahar J, Lajis NH, et al. A new ring-reduced tetraprenyltoluquinone and aprenylated xanthone from Garcinia cowa. Aust J Chem 2004;57(3):223-6. http://dx.doi.org/10.1071/CH03175

6. Wahyuni FS, Shaari K, Stanslas J, Lajis NH. Dachriyanus, Cytotoxic xanthones from the stem bark of Garcinia cowa Roxb. J Chem. Pharm Res. 2015;7(1):22736.

7. Dirsch, VM, Stuppner H, Vollmar AM. The Griess Assay: Suitable for a BioGuided Fractionation of Anti-inflammatory Plant Extracts? Planta Med. 1998 64(05):423-6. http://dx.doi.org/10.1055/s-2006-957473 ; PMid:9690344

8. Heras BDL, Abad MJ, Silvan AM, Pascual R, Bermejo P, Rodriguez B, et al. Effects of six diterpenes on macrophage eicosanoid biosynthesis. Life Sciences. 2001;70(3):269-78. http://dx.doi.org/10.1016/S0024-3205(01)01402-3

9. Coleman JW. Nitric oxide in immunity and inflammation. Intl Immunopharmacol. 2001;1(8):1397-406. http://dx.doi.org/10.1016/S1567-5769(01)00086-8

10. Ricart-Jane' D, Lobera M, Lo'pez-Tejerol MD. Anticoagulants and Other PreanaIytical Factors Interfere in Plasma Nitrate/Nitrite Quantification by the Griess Method. Nitric oxide: Biology and Chemistry. 2002;6(2):178-85. http://dx.doi. org/10.1006/niox.2001.0392; PMid:11890742.

11. Chen LG, Yang LL, Wang CC. Anti-inflammatory activity of mangostins from Garcinia mangostana. Food and Chem Toxicol. 2008;46(2):688-93. http://dx.doi. org/10.1016/j.fct.2007.09.096; PMid:18029076.

\section{PICTORIAL ABSTRACT \\ Isolated Compounds from Garcinia cowa}

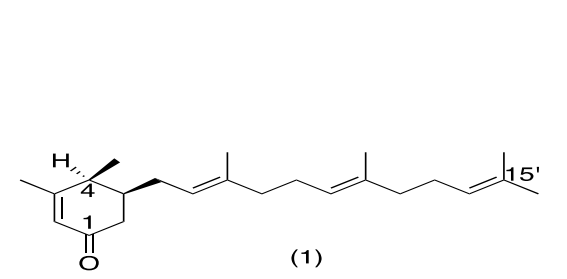

(1)

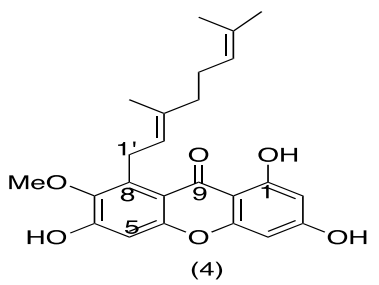

(4)

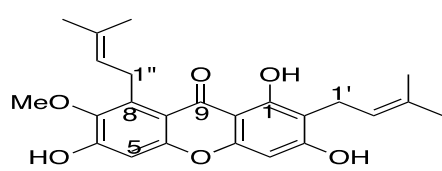

(5)

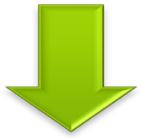

NO inhibitory activity of isolated compounds.

\begin{tabular}{llll}
\hline No & Compounds & $\%$ inhibition of NO & $\%$ viability of RAW cell \\
\hline & & $(50 \mu \mathrm{M})$ & $(50 \mu \mathrm{M})$ \\
1. & Tetrapreniltoluquinone (1) & 81 & 40 \\
2. & rubraxanthone (4) & 24 & 77 \\
3. & $\alpha$-mangostin (5) & 83 & 82
\end{tabular}

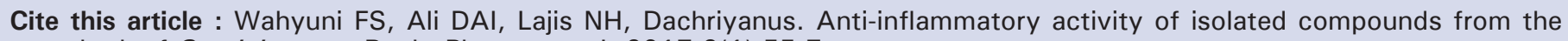
stem bark of Garcinia cowa Roxb. Pharmacog J. 2017;9(1):55-7. 